\title{
EVALUATION OF THE REDUCING ABILITY OF ANION EXCHANGE RESIN AV-17-8 IN THE SULPHITE FORM
}

\author{
National Technical University of Ukraine "Kyiv Polytechnic Institute" \\ 37, Peremogy Ave., 03056 Kyiv, Ukraine \\ tamazashvili@gmail.com
}

Received: M ay 14, 2013 / Revised: J une 07, 2013 / Accepted: N ovember 02, 2013

(C) Tamazashvili A., Makarenko I., 2015

\begin{abstract}
The removal of dissolved oxygen (DO) from water was studied using anion exchange resin AV-17-8 in a sulphite form. The effects of various operating conditions, such as water flow rates, height of the resin bed and mineralization of water on the removal of DO have been studied extensively. It was shown that its reducing ability depends on the water ionic composition that affects the desorption rate of the sulphite anions. The possibility of efficient water deoxygenation at ambient temperature was demonstrated. The mechanism of chlorate anions reduction on the anion exchanger was determined.
\end{abstract}

Keywords: dissolved oxygen, anion exchange resin, sulphite, capacity.

\section{Introduction}

Pollution of water bodies - the sources of drinking water - in the absence of effective technologies of water treatment and with unsatisfactory condition of water supply systems creates a risk to public health in many regions of Ukraine. In the industrial regions natural water bodies' contamination occurs due to sewage discharge of the industrial enterprises, power plants and mines. In some regions potable water has unacceptably high salinity and hardness and groundwater used for drinking is contaminated with ions of iron and manganese, nitrites and nitrates. This adversely affects the health of the population. The only correct approach to solve the complex problem of protecting water from contamination is the widespread adoption of closed systems of water use in industry and energy. Therefore, the development of modern low-waste technologies for high-quality water for the transition to the closed systems of water use, and their reliable operation is an urgent and important issue.
The corrosion of metal pipes in water distribution networks is a complex electrochemical and physicochemical phenomenon between a metal surface and corrosive water, which cannot always be eliminated but can usually be controlled by cost-effective manner [1]. Corrosion of system pipes has economic, hydraulic and aesthetic impacts, including water leaks, corrosion product build up, increased pumping costs, and water contamination.

The corrosiveness of water depends on chemical factors, such as $\mathrm{pH}$, alkalinity, dissolved oxygen, carbon dioxide, total dissolved solids (TDS), and physical properties, such as temperature, flow and velocity, as well as nature of the pipe material [1].

In neutral aqueous medium at power plants corrosive processes are usually caused by the presence of dissolved oxygen [2].

Thus, during operation of these plants considerable attention is devoted to the water chemical regime, the low oxygen content being one of the indicators.

There are physical, chemical, and catalytic methods for water deoxygenation, and all of them have drawbacks. Physical deoxygenation methods, such as vacuum degassing are incapable of reducing oxygen to the desired level. Furthermore, the physical methods are very energyintensive. Chemical methods employ reducing agents (hydrazine, sulfites, etc.) contaminating both the environment and water being purified [3].

Methods for the removal of oxygen from water using polymer materials are currently under development. These methods include oxidation-reduction and catalytic techniques.

When using redox ion exchangers the required degree of oxygen removal is achieved through appropriate choice of the redox material, its fractional composition, the column height, and the flow rate of water [4]. 


\section{Experimental}

The objective of this research is the creation of modified ion-exchange materials on the basis of strongly basic anion exchange resin $\mathrm{AV}-17-8$ in $\mathrm{SO}_{3}{ }^{2-}$ and determination of the conditions for the effective removal of dissolved oxygen from water, exploring the influence of the type of oxidizing agent on the reducing ability of obtained reducing-oxidizing ion exchange resin.

Removal of dissolved oxygen (DO) from water on anion exchange resin in a sulfite form is described in [5]. It mainly concerns desalted water or condensate. However it is unknown how deoxygenation will happen while using water without desalting. In this case, the process primarily will be affected by anions. Therefore application of redox ion exhange resin of this type can be problematic both in cooling systems, which use natural water without treatment or partially softened and in water-heating straight through boilers which use softened water. Partial decrease in hydrocarbonates is possible using reagent softening, while sodium cation softening usually does not influence the concentration of anions in water.

During the studies the anion exchange resin AV17-8 was used in $\mathrm{Cl}^{-}$-form and $\mathrm{SO}_{4}{ }^{2-}$-form with bed volume of 20-50 ml. Exploring the properties of modified ion exchanger water solutions were infiltrated through the resin bed at a flow rate from $1-5$ to $20-50 \mathrm{ml} / \mathrm{min}$. The sample volume ranged from $100 \mathrm{ml}$ to 21 . The samples were analyzed for outlet DO content, sulfites, sulfates, chlorides, hydro carbonates, and chlorates content. During deoxygenation process samples were collected in the measuring flask fully filled with water. Water was supplied to the bottom of the flask through the thin pipe with water ousting. It prevented samples from ingress of atmospheric oxygen.

For assessment of reducing ability of redox ion exchange resin the test solutions were used: tap water (total hardness $4.0-5.1 \mathrm{mg}$-eq/l, alkalinity $3.9-5.0 \mathrm{mg}$-eq/l, $\left.\left[\mathrm{Cl}^{-}\right]=50-62 \mathrm{mg} / \mathrm{l} ;\left[\mathrm{SO}_{4}^{2-}\right]=17-20 \mathrm{mg} / \mathrm{l}\right)$, sodium chloride solutions in tap water $\left(\left[\mathrm{Cl}^{-}\right]=70-1500 \mathrm{mg} / \mathrm{l}\right)$, sodium chlorate solutions in tap water $\left(\left[\mathrm{ClO}_{3}\right]=\right.$ $=100-300 \mathrm{mg}$-eq $/ \mathrm{l})$.

To evaluate the reducing ability of redox ion exchange resin under static conditions the sodium chloride solutions at volume of $500 \mathrm{ml}\left(\left[\mathrm{ClO}_{3}{ }^{-}\right]=20-150 \mathrm{mg}\right.$-eq $\left./ \mathrm{l}\right)$ were added to $10 \mathrm{ml}$ of the anion exchange resin. DO in samples was determined by the Winkler's titrimetric method.

\section{Results and Discussion}

Exchange capacity of ion exchange resin for sulfite ions under dynamic conditions ranged from $0.4-1.2 \mathrm{~g}$-eq/1 when using $5 \%$ solution of sodium sulfite and when using $10 \%$ solution it ranged to $1.7-2.1 \mathrm{~g}$-eq/l.

Reducing ability of obtained redox ion exchanger for DO was investigated under dynamic conditions using tap water. According to Fig. 1 the reducing ability of anion exchanger raises with the increase in exchange capacity for sulfites. However, even in tap water that has relatively low content of irrelevant ions $\left(\left[\mathrm{Cl}^{-}\right]=62 \mathrm{mg} / \mathrm{l}\right.$, $\left.\left[\mathrm{SO}_{4}{ }^{2-}\right]=20 \mathrm{mg} / \mathrm{l},\left[\mathrm{HCO}_{3}{ }^{-}\right]=3.9 \mathrm{mg} / \mathrm{l}\right)$ the reducing ability runs up to $63.4 \%$ of theoretically possible with the exchange capacity for $\mathrm{SO}_{3}{ }^{2-}=1.83 \mathrm{~g}$-eq/l and $74.8 \%$ with the exchange capacity for $\mathrm{SO}_{3}{ }^{2-}=0.642 \mathrm{~g}$-eq/l.

For the solution of sodium chloride in tap water at the concentration of chlorides $956 \mathrm{mg} / \mathrm{l}$ the reducing ability appeared to be $0.53 \mathrm{~g}$-eq/l with the capacity for $\mathrm{SO}_{3}{ }^{2-}=1.99 \mathrm{~g}-\mathrm{eq} / \mathrm{l}$. Thus, it reached only $26.6 \%$ of theoretically possible.

As for two first mentioned cases we can talk about random oxidation of sulfites on the anion exchanger with the atmospheric oxygen (although the process was carried out using reliable rubber seals, water was fed to the bottom of the volumetric flask with a narrow neck, with a constant displacement of water from a volumetric flask), in the third case, there is a negative effect of chlorides, which obviously cause desorption of the sulfite from the anion exchanger.

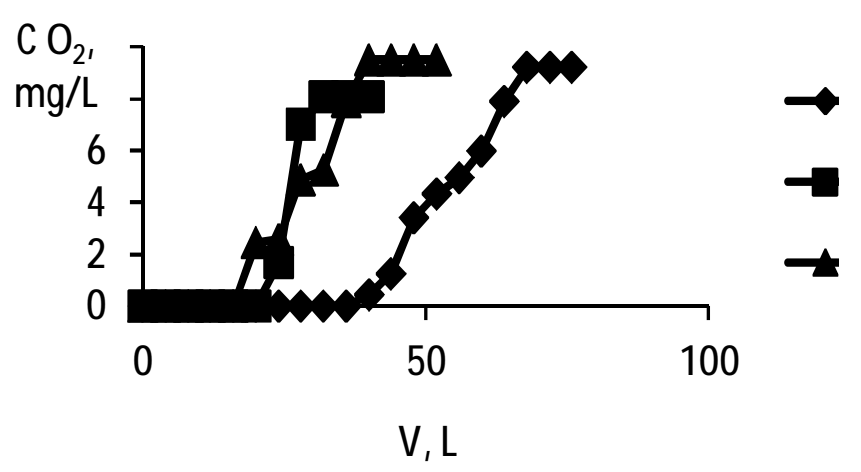

Fig. 1. Dependence of outlet DO concentration on tap water volume $(1,2)$ or sodium chloride solution in tap water $\left(\left[\mathrm{Cl}^{-}\right]=956 \mathrm{mg} / \mathrm{l}\right)(3)$ infiltrated through the anion exchanger $\mathrm{AV}-17-8$ in $\mathrm{SO}_{3}{ }^{2-}$-form $(V=50 \mathrm{ml})$ at the inlet $\mathrm{DO}$ concentration $9.24 \mathrm{mg} / \mathrm{l}(1) ; 8.08 \mathrm{mg} / \mathrm{l}(2)$ and $9.50 \mathrm{mg} / \mathrm{l}$ (3) with the exchange capacity for sulfites $1.83 \mathrm{~g}$-eq/l (1); $0.642 \mathrm{~g}$-eq/1

(2) and $1.99 \mathrm{~g}$-eq/l (3). Reducing ability $\left(\mathrm{RA}_{1}\right)=1.16 \mathrm{~g}$-eq/1; $\mathrm{RA}_{2}=0.48 \mathrm{~g}-\mathrm{eq} / \mathrm{l}$ and $\mathrm{RA}_{3}=0.53 \mathrm{~g}-\mathrm{eq} / \mathrm{l}$

The quantity of displaced sulfite ions is significantly higher than the concentration of DO in water, causing a significant reduction in time of protective action of anion exchanger (decrease in the reducing ability).

In this connection it was interesting to determine the effect of chlorides concentration on the efficiency of 
their sorption on the anion $\mathrm{AV}-17-8$ in $\mathrm{SO}_{3}{ }^{2-}$-form. Also, desorption of sulfite was a question of importance. Since the low concentrations of sulfites in water because of sulfite oxidation by the atmospheric oxygen the results of their concentration determination are significantly understated. Therefore the control was mainly carried out by chlorides concentration using the ionometer I-160 MI.

Figs. 2 and 3 illustrate the dependence of outlet concentration of chlorides and sulfites on the flow volume of sodium chloride solutions. As can be seen in Fig. 2 the increase in the concentration of chlorides from 453 to $955 \mathrm{mg} / \mathrm{l}$ leads to the rise in the exchange capacity of anion exchanger for chlorides from 0.790 to $1.458 \mathrm{~g}$-eq/l. At the chlorides concentration of $110 \mathrm{mg} / \mathrm{l}$ (Fig. 3) the exchange capacity decreases to $0.33 \mathrm{~g}$-eq/l while chlorides at the concentration of $70 \mathrm{mg} / \mathrm{l}$ almost do not absorbed on the anion exchange resin and do not displace sulfite anions.

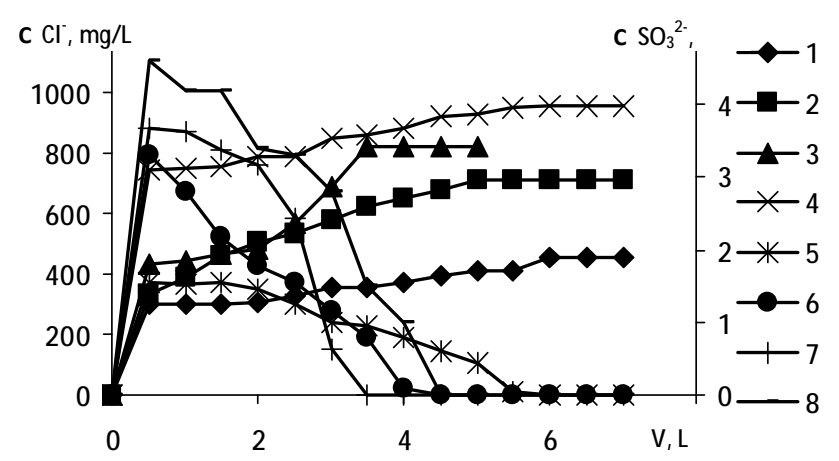

Fig. 2. Dependence of the outlet concentration of chloride (1-4) and sulfite anions (5-8) on the volume of the sodium chloride solutions with concentration of $453(1,5) ; 709(2,6) ; 824(3,7)$ and $956(4,8) \mathrm{mg} / \mathrm{l}$ infiltrated through anion exchange resin $\mathrm{AV}-17-8(V=20 \mathrm{ml})$ in the $\mathrm{SO}_{3}{ }^{2-}$-form with the exchange capacity for sulfites (g-eq/l): $2.06(1,5) ; 1.78(2,5) ; 1.83(3,7)$ and $1.99(4,8)$. Capacity for $\mathrm{Cl}_{1}^{-}=0.790 ; \mathrm{Cl}_{2}^{-}=1.15$; $\mathrm{Cl}_{3}^{-}=1.312$ and $\mathrm{Cl}_{4}^{-}=1.458 \mathrm{~g}-\mathrm{eq} / \mathrm{l}$

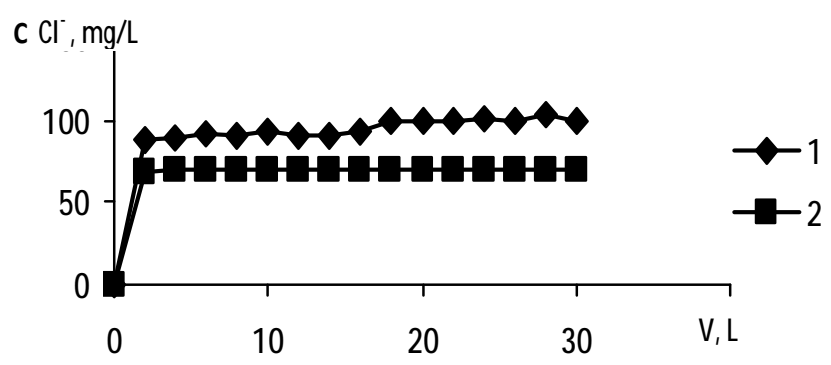

Fig. 3. Dependence of the outlet concentration of chlorides $(1,2)$ on the volume of sodium chloride solutions at the concentrations of 110 (1) and 70 (2) $\mathrm{mg} / \mathrm{l}$ infiltrated through the anion exchange resin $\mathrm{AV}-17-8$ in $\mathrm{SO}_{3}{ }^{2-}$-form with the exchange capacity for sulfites (g-eq/l): 1.800 (1) and 1.760 (2).

Capacity for $\mathrm{Cl}^{-}=0.330 \mathrm{~g}$-eq/l
Concerning the results the decrease in the reducing ability of modified anion exchanger in the sodium chloride solution (Fig. 1, curve 3) can be easily explained. Chloride caused leaching of sulfites anion in amounts far exceeding the oxygen content in water which led to the decrease in the reducing ability. But why there was the decrease in the reducing ability up to $25-37 \%$ in tap water, in which the total content of chlorides and sulfates reached only $82 \mathrm{mg} / \mathrm{l}$. Displacement of sulfite anions by the hydrocarbonates is unlikely due to the low selectivity of the resin for the latter. However it was determined that hydrocarbonates can displace sulfite anions at the concentration of $6 \mathrm{mg}$-eq/l.

With increasing concentrations of hydrocarbonates their sorption on the anion exchanger $\mathrm{AV}-17-8$ in the sulfite form increases. Taking into account that alkalinity of tap water reaches $3.9 \mathrm{mg}$-eq/l, the content of chlorides is $1.75 \mathrm{mg}-\mathrm{eq} / \mathrm{l}$ and sulfates $-0.42 \mathrm{mg}$-eq/l (total anions content is $6.07 \mathrm{mg}$-eq/l), it is quite possible that displacement of sulfite anions from anion exchanger takes place. At the concentration of hydrocarbonates of $6 \mathrm{mg}$-eq/l the concentration of ions driven out raises up to $1.3-1.5 \mathrm{mg}$-eq/l. With the concentration of DO at the level of $1.0-1.1 \mathrm{mg}-\mathrm{eq} / \mathrm{l}$ the loss of sulfites at $20-35 \%$ becomes quite possible.

Assessment of reducing capacity of redox ion exchangers for water deoxygenation is quite a challenge. Even when using the exchange resin in small quantities (20-50 ml) at a relatively high capacity for reducing agent causing high reducing ability, determination of the total reducing ability requires dozens of litres of tap water to be infiltrated through the resin bed because of the low concentration of dissolved oxygen $(6-14 \mathrm{mg} / \mathrm{l})$. And at the rate of $20-50 \mathrm{ml} / \mathrm{min}$ it takes much time. Therefore concentrated solutions of oxidant such as sodium chlorate may be used for the quick test to determine the reducing ability of redox ion exchanger.

Another thing worth mentioning is that studying the reducing process of chlorate anions on the modified anion exchanger in the sulfite form under static conditions (Fig. 4), the reducing ability of the resin did not exceed $1.550 \mathrm{~g}$-eq/l at the capacity for sulfite $-1.945 \mathrm{~g}$-eq/l. Decrease in the reducing ability of the anion exchange resin compared with the capacity for sulfite anions is possible due to the oxidation of sulfite anions with atmospheric oxygen during the experiment. In this case a certain volume of anion exchange resin was introduced with $\mathrm{SO}_{3}{ }^{2-}$ under dynamic conditions, and then divided into samples of $10 \mathrm{ml}$ each for research under static conditions.

Furthermore, anion exchange resin after oxidation of sulfite anions can be easily regenerated. In this case, the sorption of chlorate anions was carried out on the anion exchanger. The anion exchanger was washed with $10 \%$ 
solution of sodium sulfate for the removal of adsorbed chlorate anions. After washing $\mathrm{SO}_{3}{ }^{2-}$ anions were introduced to the anion exchange resin from $10 \%$ solution of sodium sulfite.

It should be noted that the processing with sodium sulfate is eliminated after oxidation of sulfite anions with the dissolved oxygen. Under normal conditions without extraneous anions the adsorption the anion exchanger after oxidation of sulfite anions is transformed into the sulfate form. Using anion exchanger both in $\mathrm{SO}_{4}{ }^{2-}$-form and in $\mathrm{Cl}^{-}$-form its capacity for $\mathrm{SO}_{3}{ }^{2-}$ reaches $1.7-2.0 \mathrm{~g}$-eq/l after its regeneration with $10 \%$ solution of $\mathrm{Na}_{2} \mathrm{SO}_{3}$.

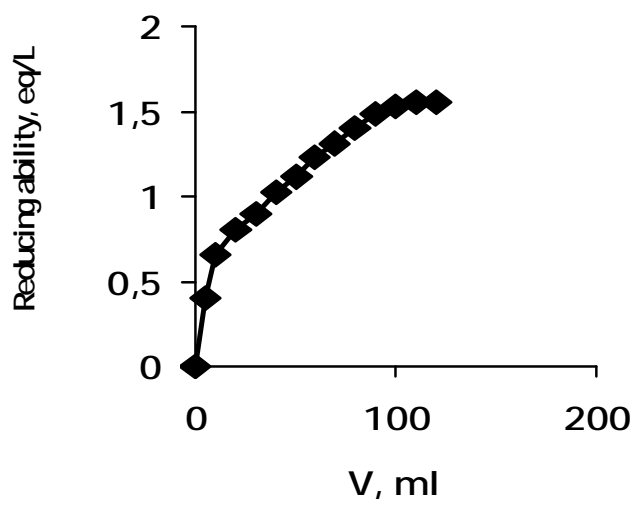

Fig. 4. Dependence of the reducing capacity of anion exchange resin $\mathrm{AV}-17-8$ in $\mathrm{SO}_{3}{ }^{2-}$-form (Exchange capacity for $\mathrm{SO}_{3}{ }^{2-}$ is $1.945 \mathrm{~g}$-eq/l) for $\mathrm{ClO}_{3}{ }^{-}$ on their equilibrium concentration in samples of $500 \mathrm{ml}$ and the volume of ion exchange resin of $10 \mathrm{ml}$

\section{Conclusions}

The reducing ability of anion exchange resin AV17-8 in the sulfite form depends on the capacity of anion exchange resin concerning sulfite anions and desorption of them in the presence of competing anions. In the case of chloride anions sorption it was shown that the desorption of sulfite anions occurs at concentrations higher than $110 \mathrm{mg} / \mathrm{l}$.

It was discovered that hydrocarbonates at concentrations exceeding $6 \mathrm{mg}$-eq/l can cause a decrease in the reducing ability of redox ion exchanger up to $20-35 \%$.

Anion exchange resin AV-17-8 in the sulfite form should be used for deaeration of water containing anions at the concentration less than $6 \mathrm{mg}-\mathrm{eq} / \mathrm{l}$.

An assessment of reducing ability of the modified anion exchange resin was made with the help of model solutions of sodium chlorate. It was shown that highly basic anion exchange resin AV-17-8 can be easily regenerated with $10 \%$ solution of sodium sulfite.

\section{References}

[1] Do-Hwan Kim, Jae-Hwan Cha, Soon-Heon Hong et al.: Korean J. Chem. Eng., 2009, 26, 90.

[2] Kudinov A., Solodyannikova Y., Tsabilev O. and Obukhov D.: Power Techn. Eng., 2009, 43, 131.

[3] Lebedeva V., Gryaznov V., Petrova I. et al.: Kinetika i Kataliz, 2006, 47, 867.

[4] Kravchenko T. and Nikolaev N.: Kinetyka i Dinamika v Redoksytakh. Khimiya, Moskwa 1982.

[5] Shatalov V., Nikonov V., Kudrayvcev V. et al.: Pat. 2217382, MKI7 C 02 F 1/20, 1/42, Publ. Jun. 17, 2002.

\section{ОЦІНКА ВІДНОВЛЮВАЛЬНОЇ ЗДАТНОСТІ АНІОНІТУ АВ-17-8 В СУЛЬФІТНІЙ ФОРМІ}

Анотація. 3 використанням аніоніту АB-17-8 в сульфітній формі вивчено видалення з води розчиненого в ній кисню. Встановлено вплив різних умов експлуатації, таких як витрата води, висота шару завантаження та мінералізація води. Показано, шо відновлювальна здатність йоніту залежить від йонного складу води, шуо визначає ефективність десорбиіі сульфіт аніонів. Продемонстрована можсливість ефективного знекиснення води за температури навколишнього середовища. Встановлено механізм відновлення хлорат аніонів на отриманому аніоніті.

Ключові слова: розчинений кисень, аніоніт, сульфіт, ємність 